\title{
Mitochondrial 3 beta-hydroxysteroid dehydrogenase (HSD) is essential for the synthesis of progesterone by corpora lutea: An hypothesis

\author{
John C Chapman ${ }^{1}$, Jose R Polanco ${ }^{1,2}$, Soohong Min ${ }^{1}$ and Sandra D Michael*1
}

Address: ${ }^{1}$ Department of Biological Sciences, Binghamton University, Binghamton, NY 13902-6000, USA and ${ }^{2}$ Notre Dame Ambulatory Care Center, Medical Director, 1000 Broad Street, Central Falls, RI 02863, USA

Email: John C Chapman - johnchapman1@juno.com; Jose R Polanco - jpolancomd@cox.net; Soohong Min - soohongmin@juno.com; Sandra D Michael* - smichael@binghamton.edu

* Corresponding author

Published: 03 April 2005

Reproductive Biology and Endocrinology 2005, 3:1 I doi:10.1 I86/1477-7827-3-1।

This article is available from: http://www.rbej.com/content/3/I/II

(c) 2005 Chapman et al; licensee BioMed Central Ltd.

This is an Open Access article distributed under the terms of the Creative Commons Attribution License (http://creativecommons.org/licenses/by/2.0), which permits unrestricted use, distribution, and reproduction in any medium, provided the original work is properly cited.
Received: 12 January 2005

Accepted: 03 April 2005

\begin{abstract}
In mouse ovaries, the enzyme 3 beta-hydroxysteroid dehydrogenase (HSD) is distributed between microsomes and mitochondria. Throughout the follicular phase of the estrous cycle, the HSD activity in microsomes is predominant; whereas, after LH stimulation, HSD activity during the luteal phase is highest in the mitochondria. The current study examined whether or not $\mathrm{LH}$ stimulation always results in an increase in mitochondrial HSD activity. This was accomplished by measuring the HSD activity in microsomal and mitochondrial fractions from ovaries of pregnant mice. These animals have two peaks of $\mathrm{LH}$ during gestation, and one peak of $\mathrm{LH}$ after parturition. It was found that mitochondrial HSD activity was highest after each peak of LH. It is proposed that mitochondrial HSD is essential for the synthesis of high levels of progesterone. The increase in HSD activity in mitochondria after $\mathrm{LH}$ stimulation occurs because: I) $\mathrm{LH}$ initiates the simultaneous synthesis of HSD and the cholesterol side-chain cleavage enzyme (P450scc); and, 2) HSD and P450scc bind together to form a complex, which becomes inserted into the inner membrane of the mitochondria. High levels of progesterone are synthesized by mitochondrial HSD because: I) the requisite NAD+ cofactor for progesterone synthesis is provided directly by the mitochondria, rather than indirectly via the rate limiting malate-aspartate shuttle; and, 2) the end-product inhibition of P450scc by pregnenolone is eliminated because pregnenolone is converted to progesterone.
\end{abstract}

\section{Background}

With the exception of $3 \beta$-hydroxysteroid dehydrogenase (HSD), the enzymes involved in the conversion of cholesterol to steroid hormones are located in either the mitochondria or the endoplasmic reticulum. HSD is unique in that it is located in both subcellular organelles. In either location, HSD converts pregnenolone and dehydroepiandosterone (DHEA) to progesterone and androstenedione, respectively, using $\mathrm{NAD}^{+}$as cofactor. The reason for two separate sites for this enzyme is not known.

Establishing the existence of two separate locations for HSD has been a lengthy process. In 1956, Beyer and Samuels reported that the microsomal (endoplasmic reticulum) and mitochondrial fractions from the homogenate of bovine adrenal cortex contained HSD activity [1]. 
However, the HSD activity found in the mitochondrial fraction was attributed to microsomal contamination and the result of the homogenizion process. While this study established the legitimacy of microsomal HSD, it tended to preclude further research on mitochondrial HSD. For mitochondrial HSD to be considered a distinct and separate entity, additional research over a number of years would be required. Starting in 1965, investigators began to report a dual location for HSD in ovaries [2-4], testes [5,6], human term placenta [7-10], and rat adrenal cortex [11-14]. In toto, these studies suggested that mitochondrial HSD was indeed a separate entity. Other investigators, however, still considered mitochondrial HSD activity to be due to microsomal contamination $[15,16]$, and the result of a redistribution artifact [17].

In 1979, we reported the results of an intracellular enzyme distribution study of HSD, cytochrome c oxidase (mitochondrial marker), and steroid 21 hydroxylase (microsomal marker) in rat adrenal cortex [18]. We found that exhaustively washed mitochondria retained $26 \%$ of total HSD activity. In retrospect, this percentage appears to be on the low side. For example, when the specific activity of microsomal HSD is determined, and its contribution to the HSD activity in the remaining cell fractions (nuclear/ unbroken cell, mitochondrial, and mitochondrial wash fractions) ascertained, then a maximum of $60 \%$ of total homogenate HSD activity can be attributed to microsomal HSD. This indicates that mitochondrial HSD constitutes $40 \%$ of total homogenate HSD activity, rather than $26 \%$ as we initially reported. In rhesus monkey placenta, HSD activity is equally distributed between mitochondria and microsomes [19], and in bovine adrenal cortex, mitochondrial HSD comprises $30 \%$ of total HSD activity $[20,21]$.

Our study also found that mitochondrial HSD utilizes matrix space $\mathrm{NAD}^{+}$as cofactor, indicating that the enzyme is located in the inner mitochondrial membrane [18]. This location for mitochondrial HSD has been established in bovine adrenal cortex $[20,21]$, and in rat testis [5]. The combined techniques of immuno-cytochemistry and electron microscopy have identified immune reactive HSD in mitochondria of human ovary [22], and in the mitochondria of rat ovary, testis, and adrenal cortex [23]. Mitochondrial HSD has now been isolated from bovine adrenal cortex $[21,24]$, and from human term placenta $[25,26]$, and purified to homogeneity. It is now known that microsomal HSD and mitochondrial HSD are identical proteins [25-28]. The reason for two locations for the same enzyme has yet to be determined.

In a study of the intracellular distribution of mitochondrial HSD and microsomal HSD in mouse ovaries over the course of the estrous cycle [29], we reported that dur- ing diestrus (luteal phase), the specific activity of mitochondrial HSD was $80 \%$ higher than that of microsomal HSD. This is in sharp contrast to the other three stages of estrus where microsomal HSD had the highest specific activity. In a study in which the cDNA of human placental HSD was transfected into Sf9 cells, the resultant HSD enzyme was distributed between mitochondria and microsomes [27]. In the luteal cells of mouse ovary, the distribution of the enzyme is skewed in favor of the mitochondria. During the luteinization process, luteal cells express high levels of mRNA for the cholesterol side-chain cleavage enzyme $\left(\mathrm{P}^{4} 50_{\mathrm{scc}}\right)$ and for HSD [30,31]. The simultaneous synthesis of these two enzymes is very likely the reason for the increase in mitochondrial HSD activity, as will be discussed later.

The results of our previous study [29] tentatively suggested that the increase in mitochondrial HSD activity in mouse ovary during diestrus is due to LH. The pregnant mouse has two peaks of LH during gestation, and one peak of LH after parturition [32]. After each peak of LH, the levels of circulating progesterone increase [33]. The present study examined the distribution of HSD activity in pregnant mouse ovaries to determine whether or not mitochondrial HSD activity also increased after each peak of LH. We found that it did, which led to our proposed explanation for the reason for two separate locations for HSD in corpora lutea.

\section{Methods \\ Animals}

Female mice of the $(\mathrm{C} 3 \mathrm{H} / \mathrm{HeJ} \times 129 / \mathrm{J}) \mathrm{F}_{1}(\mathrm{C} 31)$ hybrid were used in the study. Parental stocks were purchased from Jackson Laboratories, Bar Harbor, ME. The mice were housed in an animal room kept at $24^{\circ} \mathrm{C}$, with controlled lighting of 14L:10D (lights on at $0600 \mathrm{hr}$ and off at $2000 \mathrm{hr}$ ). Purina lab chow (Ralston-Purina, St. Louis, $\mathrm{MO}$ ) and water were provided ad libitum. The C31 offspring were weaned at 23-28 days of age. Female siblings were housed two per cage. For pregnancy experiments, C31 females were mated with C31 males. Only those with regular estrous cycles (4-5 days) were used for the study.

\section{Determining Stage of the Estrous Cycle and mating}

In order to promote a regular estrous cycle in the C31 females, cage shavings were taken from cages containing C31 males, and placed in cages containing the females. Also, male cages surrounded female cages. Vaginal smears were taken daily, usually in the afternoon. The smears were spread on a glass slide in a drop of physiological saline, stained using hematoxylin and eosin $\mathrm{Y}$, and the stage of estrous determined by the method of Rugh [34].

In all experiments, each study group consisted of six females that were between 80 and 190 days of age. Two of 
the study groups were comprised of animals that were in diestrus and proestrus. The remaining groups all consisted of pregnant animals. These groups were formed as follows: females that were in either proestrus or estrus were mated late in the afternoon or about $2 \mathrm{hr}$ prior to lights off. At lights on the following morning, and for subsequent days if necessary, all females were inspected for the presence of vaginal plugs. The day of vaginal plug was considered as day 0 of pregnancy. Over the gestation period, pregnant females were sacrificed on days 5, 10, 15, and 20. An additional group of females was sacrificed on day 5 postpartum.

\section{Tissue Collection and Processing}

Animals were lightly etherized, weighed, and then decapitated. The ovaries were removed, trimmed of fat, weighed in pairs, and placed on an ice-filled petri dish in a few drops of homogenizing buffer (0.3\% BSA, 1 mM EDTA, $0.25 \mathrm{M}$ Sucrose, and $30 \mathrm{mM}$ Tris-HCL [pH 7.4], $4^{\circ} \mathrm{C}$ ), as per Chapman and Sauer [18]. The twelve ovaries were finely minced, then transferred to an ice-cold $5 \mathrm{ml}$ PotterElvehjem glass homogenizer. The volume of the sample was brought up to $4 \mathrm{ml}$ with additional homogenization medium, and the ovaries homogenized in the cold room $\left(4^{\circ} \mathrm{C}\right)$ with 8 complete strokes of a motorized Teflon pestle. The homogenate was then transferred to a $10 \mathrm{ml}$ centrifuge tube, and the glass homogenizer rinsed with $1 \mathrm{ml}$ of homogenizing medium. The rinse was combined with the homogenate, and a $1 \mathrm{ml}$ sample of the total homogenate removed and saved for later assay.

The uteri were removed from 10 day, 15 day, and 20 day pregnant mice. Trophoblasts were excised from the middle section of each uterine horn. After weighing, the trophoblasts were minced, and processed as described for the ovaries, except that the mince was homogenized in a Thomas glass-glass homogenizer.

\section{Differential Centrifugation}

The ovarian homogenate, contained in a $10 \mathrm{ml}$ centrifuge tube, was centrifuged at $700 \times \mathrm{g}$ in a Sorvall RC-5 refrigerated centrifuge for $10 \mathrm{~min}$. The supernatant was removed and spun at $10,000 \times \mathrm{g}$ for 20 minutes in the same centrifuge. The low-speed pellet, containing nuclei and unbroken cells, was resuspended in $1.5 \mathrm{ml}$ homogenizing buffer. Following the $10,000 \times \mathrm{g}$ centrifugation, the resultant mitochondrial pellet was resuspended in $1.5 \mathrm{ml}$ homogenizing buffer. The postmitochondrial supernatant was centrifuged in a Beckman L65 Ultracentrifuge (Beckman Co., Fullerton, CA) for $1 \mathrm{~h}$ at 105,000 $\times \mathrm{g}$. This yielded cytosol and a pellet of microsomes. Microsomes were resuspended in $1.5 \mathrm{ml}$ homogenizing buffer using a $2 \mathrm{ml}$ Potter-Elvehjem glass homogenizer with Teflon pestle. All fractions, including the total homogenate, were divided into aliquots in $12 \times 75-\mathrm{mm}$ borosilicate glass tubes, covered with Parafilm (American Can Co., Greenwich, CT), and frozen at $-10^{\circ} \mathrm{C}$. Enzymatic analyses were scheduled so that the frozen sub-cellular fractions were thawed only once prior to assay.

\section{Enzymatic Analyses and Other Assays}

The total homogenate, low speed pellet (nuclei/unbroken cells), mitochondrial, and microsomal fractions were assayed for HSD activity by measuring the conversion of pregnenolone to progesterone. Duplicate tissue samples of $50 \mu \mathrm{l}$ and $100 \mu \mathrm{l}$ were added to $15-\mathrm{ml}$ glass test tubes containing $1 \mathrm{ml}$ of incubation medium $(50 \mathrm{mM}$ sucrose, $20 \mathrm{mM} \mathrm{KC1}, 1 \mathrm{mM}$ EDTA, $30 \mathrm{mM}$ Tris-HCl [pH 7.4], $0.3 \% \mathrm{BSA}$ ), and $0.5 \mathrm{mM} \mathrm{NAD}^{+}$, as per Chapman et al. [29]. The incubates were then placed in a $37^{\circ} \mathrm{C}$ water bath and allowed to equilibrate for $5 \mathrm{~min}$. The reaction was started by the addition of $100 \mathrm{nmol}$ of pregnenolone in $10 \mu \mathrm{l}$ of ethanol. After $15 \mathrm{~min}$ of incubation, the progesterone product was extracted into $1 \mathrm{ml}$ of spectral grade heptane. The absorbency of progesterone was measured in a Gilford Response spectrophotometer (Gilford Systems, Oberlin, OH). Progesterone has an absorbency peak at $233 \mathrm{~nm}$ in heptane and a molar extinction coefficient of 17,000 [18]. In order to access the extraction efficiency of $1 \mathrm{ml}$ of heptane, known concentrations of progesterone standards were run concurrently with the tissue samples. After extraction into heptane, the absorbancy of the standards was compared to their absorbance measured directly in heptane.

Cytochrome c oxidase, an inner mitochondrial membrane marker, was assayed by the procedure of Wharton and Tzalgaloff [35]. Enzymatic activity was determined by the rate of decrease in absorbancy at $550 \mathrm{~nm}$. Protein content was measured by using the method of Bradford [36]. All assays were in duplicate. Replicate data were analyzed for significant differences using ANOVA (Dunnett, and Scheffe' F-test).

\section{Results}

The distribution of HSD activity between mitochondria and microsomes undergoes a unique shift in the transition from proestrus to diestrus. At proestrus, for example, the highest HSD activity is in the microsomes. At diestrus, in contrast, mitochondrial HSD activity is almost double that of microsomal HSD [29]. The present study re-examined this phenomenon; and, as Figure 1 shows, the activity of mitochondria HSD increases significantly at diestrus. The activity of the mitochondrial inner membrane enzyme, cytochrome c oxidase, also increases at diestrus. Total ovarian protein, in contrast, decreases.

Figure 2 contains the results of two separate experiments in which HSD activity was measured in mitochondrial and microsomal fractions during pregnancy, and 5 days 

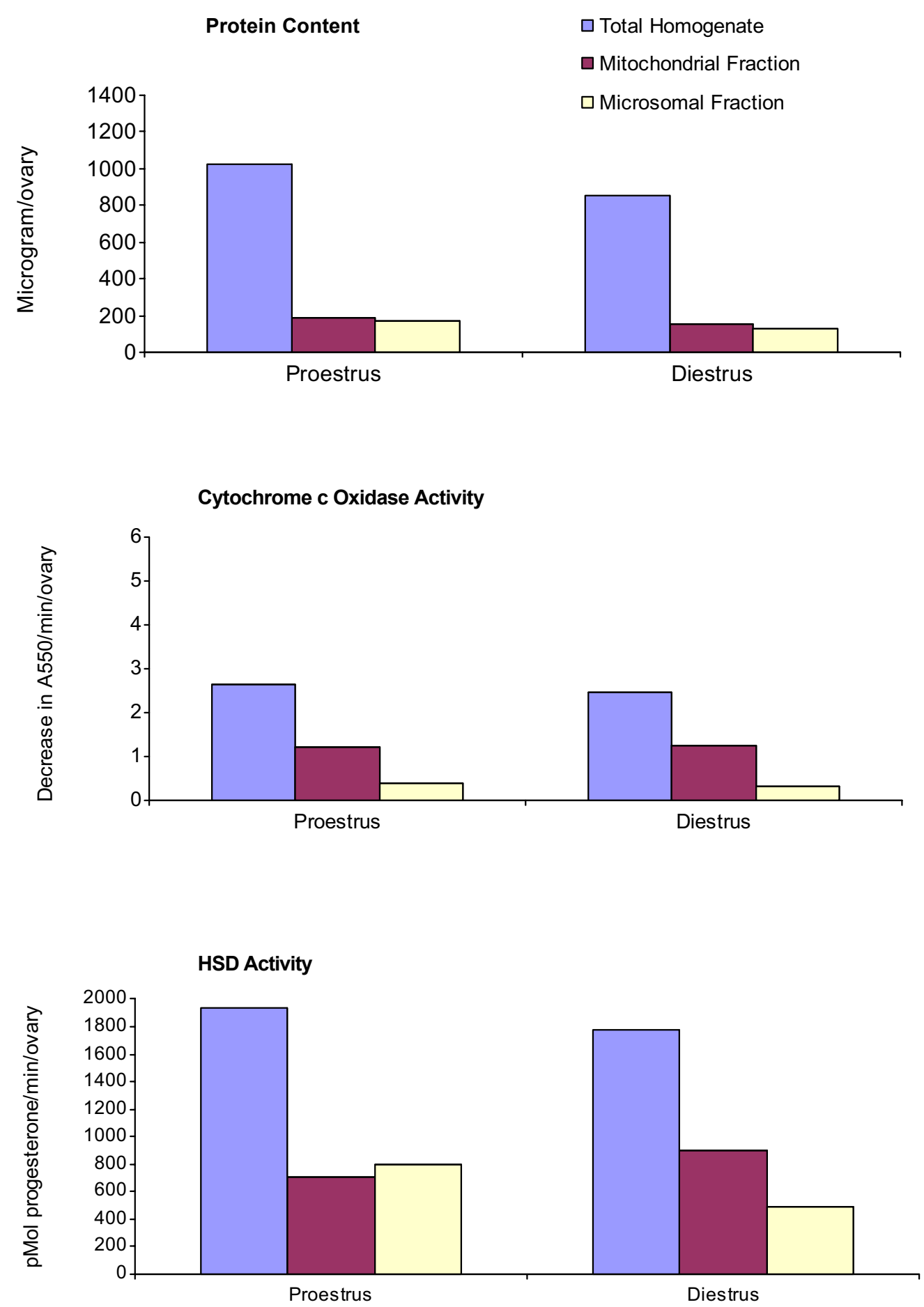

Figure I

Protein content, cytochrome c oxidase activity, and HSD activity in total homogenates, and in mitochondrial and microsomal fractions from ovaries of $\mathrm{C} 3 \mathrm{I}$ mice that were in either proestrus or diestrus. Each experimental group consisted of 6 mice. Mitochondrial and microsomal fractions were isolated by differential centrifugation. Results are expressed per individual ovary. 

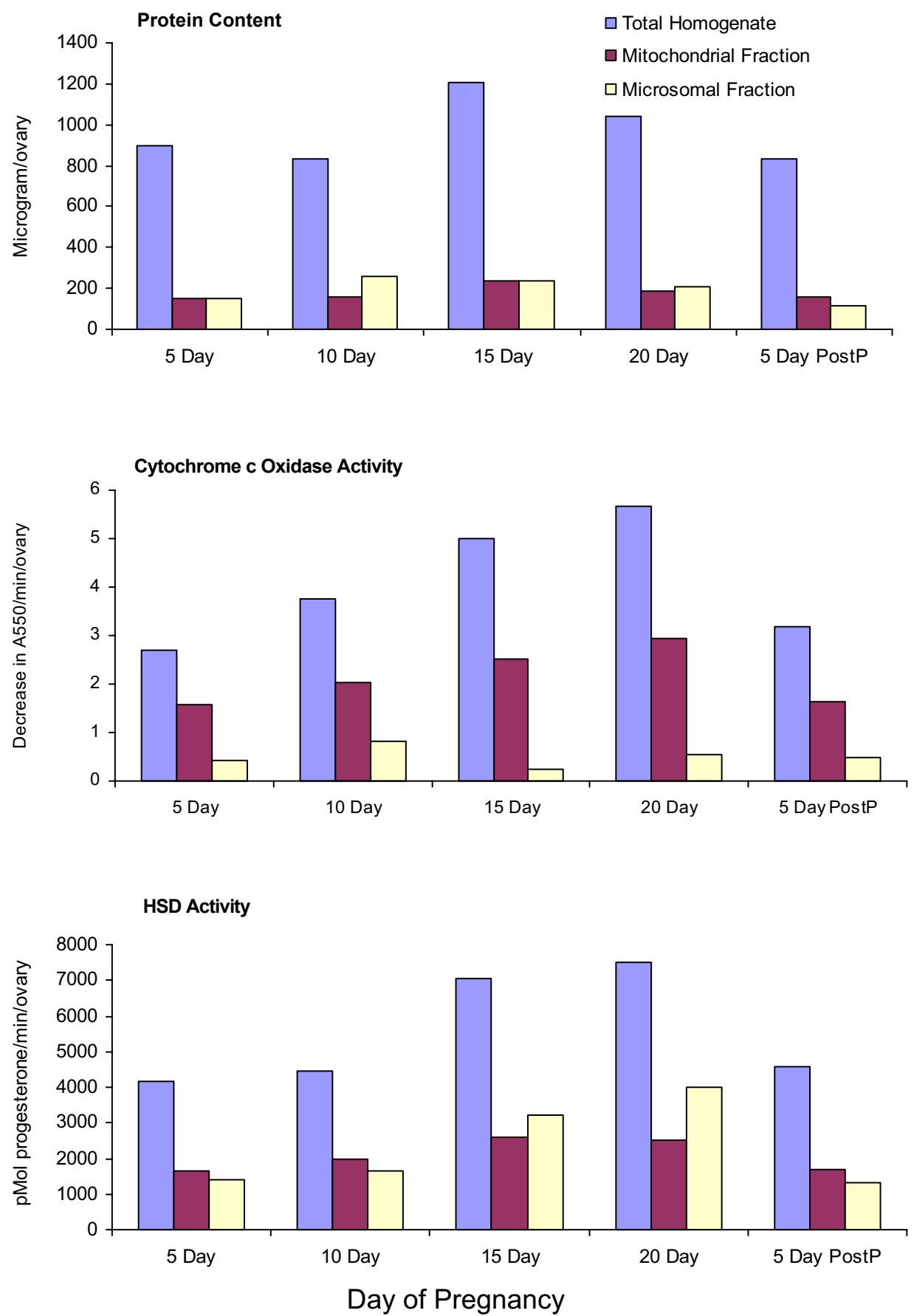

Figure 2

Protein content, cytochrome c oxidase activity, and HSD activity in total homogenates, and in mitochondrial and microsomal fractions from ovaries of $\mathrm{C} 3 \mathrm{I}$ mice that were pregnant for 5 days, 10 days, 15 days, and 20 days, or were 5 days postpartum. Each experimental group consisted of 6 mice. Mitochondrial and microsomal fractions were isolated by differential centrifugation. Results of two separate experiments are expressed per individual ovary. Statistical analyses of the enzymatic activities of cytochrome $c$ oxidase and HSD in total homogenates at each time-point showed a significant difference @ $\mathrm{P}<.05$, when compared to animals in diestrus. In addition, the HSD activities in all mitochondrial and microsomal fractions of pregnant mice were significantly different $@ P<.05$, when compared to animals in diestrus. 
after parturition. As indicated, the activities of mitochondrial HSD and microsomal HSD both increased over the course of the gestation period. However, the increase in HSD activity in the two organelles was inconsistent. For example, at 15 days and 20 days of gestation, the highest HSD activity was in the microsomal fraction. In contrast, at 5 days and 10 days of gestation, and at 5 days postpartum, mitochondrial HSD activity was greater than that of microsomal HSD. These three time points directly follow the peaks of LH [32]. Cytochrome c oxidase activity also increased during pregnancy. At day 20, cytochrome c oxidase activity was more than double the activity measured at 5 days. Total ovarian protein was inversely correlated with the peaks of LH. For example, at 15 days and 20 days of gestation, each ovary contained $1190 \mu \mathrm{g}$ protein and $1025 \mu \mathrm{g}$ protein, respectively. In contrast, at 5 days and 10 days of gestation, and at 5 days postpartum, each ovary contained $890 \mu \mathrm{g}$ protein, $825 \mu \mathrm{g}$ protein, and $810 \mu \mathrm{g}$ protein, respectively. This relationship between LH and total ovarian protein also occurs during the estrous cycle [29]. For example, as shown in Figure 1, each ovary at proestrus contained $1030 \mu \mathrm{g}$ protein; whereas at diestrus, each ovary contained $838 \mu \mathrm{g}$ protein.

Figure 3 contains the results of the measurement of HSD activity in mitochondrial and microsomal fractions of trophoblasts from 10 day, 15 day, and 20 day pregnant mice. As indicated, HSD activity was not detected (N.D.) in trophoblasts from 10 day pregnant mice. However, trophoblasts from 15 day and 20 day pregnant mice were found to produce $0.4 \mathrm{nmol}$ progesterone $/ \mathrm{min} /$ trophoblast and 0.6 nmol progesterone/min/trophoblast, respectively. Note that the highest HSD activity in trophoblasts is in the microsomal fraction.

\section{Discussion}

The results of this and the previous study [29] leave little doubt that mitochondrial HSD activity increases after LH stimulation. How the increase in mitochondrial HSD activity is achieved and for what purpose, are the topics of this discussion.

When mitochondrial HSD was initially purified from the bovine adrenal cortex, the enzyme was found to have a close association with $\mathrm{P}^{4} 50_{\text {scc }}$ [24]. This association was of such a high degree that mitochondrial HSD actually copurified with $\mathrm{P}^{4} 50_{\mathrm{scc}}$. Antibodies against mitochondrial HSD precipitated both HSD and $\mathrm{P} 450_{\text {scc }}$ and, conversely, antibodies against $\mathrm{P} 450_{\text {scc }}$ precipitated both $\mathrm{P} 450_{\text {scc }}$ and mitochondrial HSD. The degree of association between the two enzymes was measured, and a binding constant $\left(\mathrm{K}_{\mathrm{D}}\right)$ of $0.12 \mu \mathrm{M}$ was determined. As would be expected, $\mathrm{P}^{450_{\text {scc }}}$ also bound to purified microsomal HSD [24]. HSD is insoluble and inactive in an aqueous medium, due to a segment of the protein, referred to as the "membrane- spanning domain" [27]. Delete this segment and HSD becomes soluble. With the segment in place, HSD is inserted into the membranes of microsomes and mitochondria [27]. The observation that mitochondrial HSD activity increases after LH stimulation suggests that HSD is preferentially inserted into the mitochondrial membrane. The fact that HSD binds to $\mathrm{P} 450_{\text {scc }}$ is very likely the mechanism for its insertion. This suggests that HSD and $\mathrm{P} 450_{\text {scc }}$ bind together, either during, or directly after their synthesis, since it is unlikely that HSD could bind to P450 scc' $^{\prime}$ already in place. The mRNAs for HSD and $\mathrm{P}^{4} 50_{\text {scc }}$ are expressed concurrently in luteal cells of the rat [37-40], cow [41,42], sheep [42-44], horse [45], macaque monkey [46], and human [38,47-49].

Figure 4 is a representative diagram of the proposed effect of the concurrent synthesis of HSD and $\mathrm{P} 450_{\text {scc }}$ on the intracellular distribution of HSD in luteal cells. Initiated by $\mathrm{LH}$; the expression of HSD mRNA and $\mathrm{P} 450_{\text {scc }}$ mRNA results in the simultaneous synthesis of HSD and $P 450_{\text {scc. }}$. The two enzymes bind to each other to form a complex, which is then inserted into the inner mitochondrial membrane. Molecules of HSD that do not bind to $\mathrm{P}^{4} 5 \mathrm{scc}_{\mathrm{scc}}$ are inserted into the membrane of the endoplasmic reticulum.

In the mouse there are peaks of estradiol- $17 \beta$ at proestrus $(100 \mathrm{pg} / \mathrm{ml})$ and metestrus $(200 \mathrm{pg} / \mathrm{ml})$ [29]. However, these levels are significantly less than the levels of progesterone produced throughout the luteal phase. During pregnancy the levels of circulating progesterone are even higher. One could argue that the increased levels of circulating progesterone in pregnant mice are due to the HSD activity in trophoblasts. This possibility was addressed in the current study. As shown in Figure 3, homogenates of individual trophoblasts from 15 day and 20 day pregnant mice are capable of producing $0.4 \mathrm{nmol}$ progesterone/ $\mathrm{min} /$ trophoblast and $0.6 \mathrm{nmol}$ progesterone/min/trophoblast, respectively. This level of HSD activity in a single trophoblast is only $3 \%$ of the HSD activity produced by the paired ovaries. However, large litters would increase the percentage. At day 10 there is no question that the ovaries are the major source of circulating progesterone, which averages $55 \mathrm{ng} / \mathrm{ml}$ [33]. This level of progesterone is between 275 fold and 550 fold of the peak levels of estradiol-17 $\beta$ produced during the follicular phase.

In order for luteal cells to synthesize high levels of progesterone, a number of events have to occur. First, higher levels of the two enzymes, P-450 scc and HSD, have to be produced. This event is initiated when their respective mRNAs are expressed, as referenced above. Secondly, the increase in steroid synthesis requires an increased supply of cholesterol. This is achieved by removing cholesterol from cholesterol ester stores [50,51], and by initiating the 

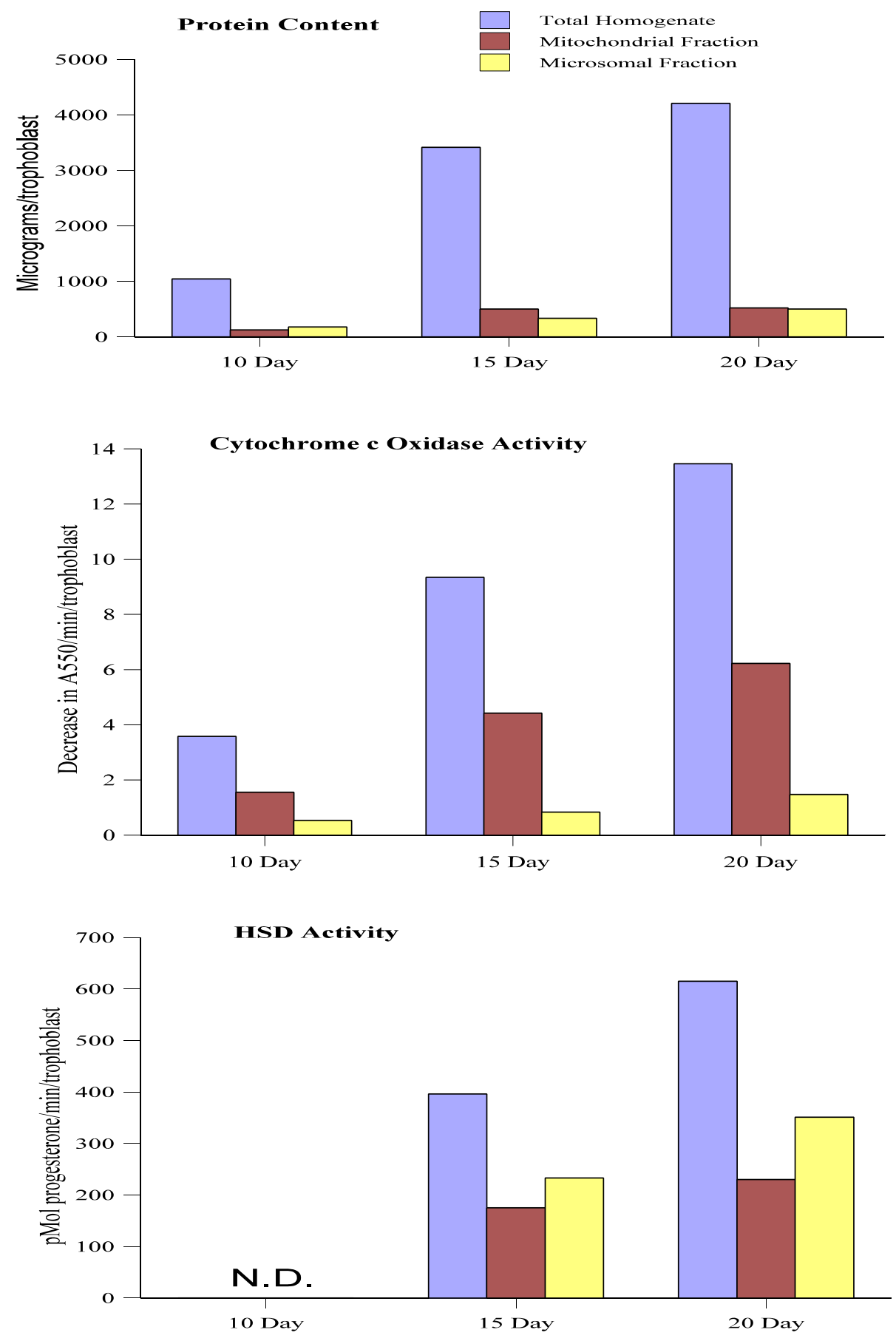

Day of Pregnancy

\section{Figure 3}

Protein content, cytochrome c oxidase activity, and HSD activity in total homogenates, and in mitochondrial and microsomal fractions from trophoblasts of C3I mice that were pregnant for 10 days, 15 days, and 20 days. Each experimental group in the 10 day and 20 day pregnant animals consisted of 6 mice. $N=12$ for the 15 day pregnant group. Mitochondrial and microsomal fractions were isolated by differential centrifugation. Results are expressed per individual trophoblast. N.D. = Not detected. 


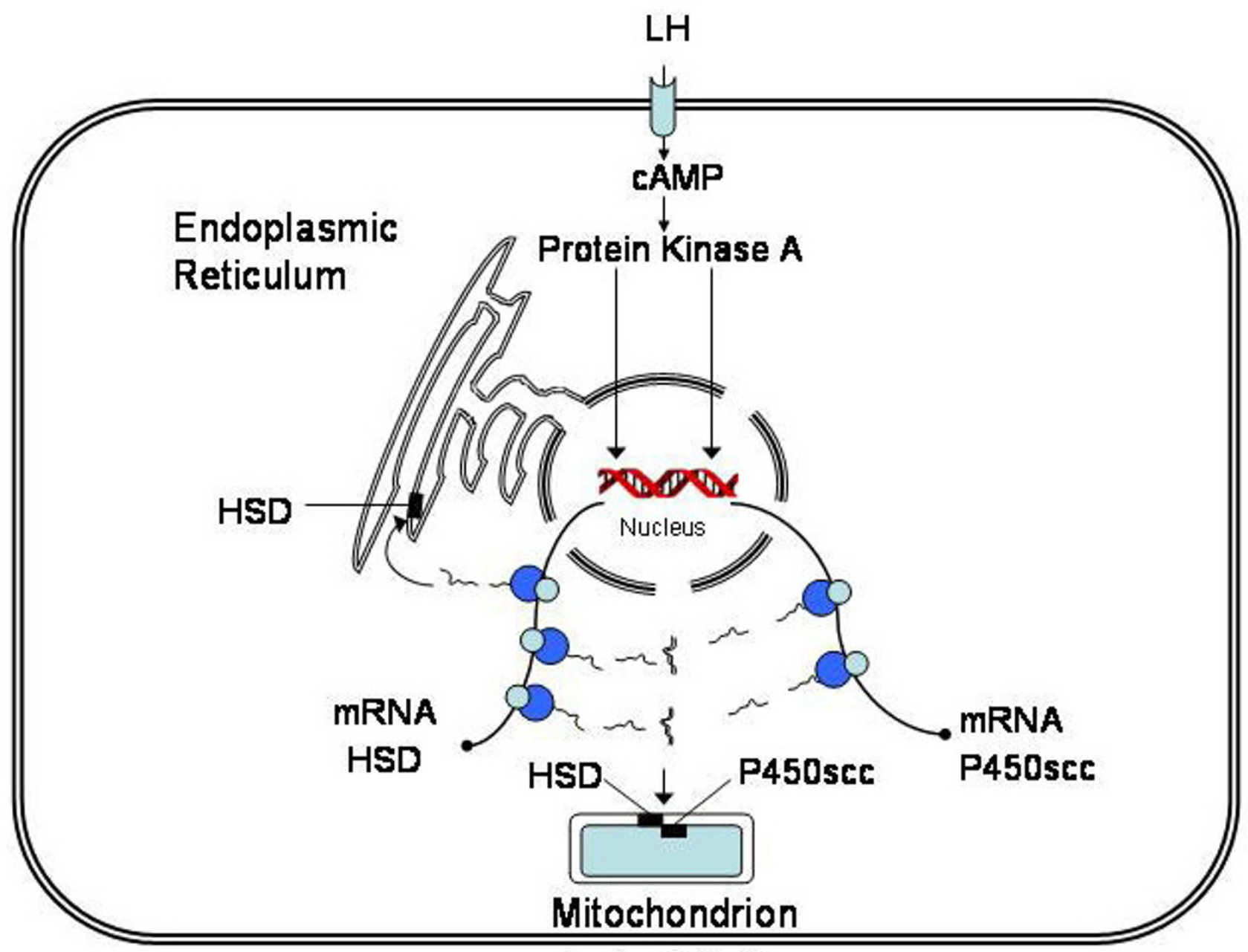

Figure 4

Representative diagram of the proposed effect of the concurrent synthesis of HSD and cytochrome P450 ${ }_{\text {scc }}$ on the intracellular distribution of HSD in luteal cells. Initiated by LH; the transcription of HSD mRNA and P450 ${ }_{\text {scc }} \mathrm{mRNA}$ results in the simultaneous production of HSD and $\mathrm{P}^{4} 50_{\text {scc }}$. The two enzymes bind to each other to form a complex, which is then inserted into the inner mitochondrial membrane. Molecules of HSD that do not bind to $\mathrm{P}^{450_{\text {scc }}}$ are inserted into the membrane of the endoplasmic reticulum.

de novo synthesis of cholesterol [52-54]. The latter event is quite likely in anticipation of fertilization of the ova and the need for a supply of cholesterol beyond diestrus. In the pregnant mouse, luteal cells synthesize high levels of progesterone for three weeks [33]. The de novo synthesis of cholesterol requires a carbon source, as well as ATP and $\mathrm{NADPH}$. In luteal cells the carbon source is acetate; ATP is generated through glycolysis; and NADPH is produced during the oxidative decarboxylation of isocitrate and malate [54]. The enzymes that catalyze the latter reaction are $\mathrm{NADP}^{+-}$-linked isocitrate dehydrogenase and NADP+linked malate dehydrogenase. Both enzymes are in abundance in the cytoplasm of luteal cells [55].
The enzyme, $\mathrm{P} 450_{\text {scc }}$ is capable of producing $53 \mathrm{nmol}$ pregnenolone $/ \mathrm{min} / \mathrm{mg}$ protein [56]. This requires an undiminished supply of NADPH, as well as the aforementioned cholesterol. The NADPH that is produced in the cytoplasm is of no direct use to the $\mathrm{P} 50_{\mathrm{scc}}$ enzyme. However, reducing equivalents from NADPH can be transferred from the cytoplasm to mitochondria via the malate-aspartate shuttle [57,58]. Unfortunately, the mitochondria in luteal tissue lack an NADP+-linked malate dehydrogenase $[59,60]$. As a result, NADPH cannot be generated in the mitochondria by the oxidative decarboxylation of malate. This is in sharp contrast to adrenal cortex tissue, which does have a mitochondrial 
NADP+-linked malate dehydrogenase [61,62]. In luteal tissue the mitochondria and cytoplasm both contain an $\mathrm{NAD}^{+}$-linked malate dehydrogenase, each enzyme having a high specific activity $[55,59]$. This indicates that there is ample capacity to transfer reducing equivalents from $\mathrm{NADH}$ into the mitochondria. If this transfer were to occur in tissues such as liver and heart, the NADH would be used to produce ATP. In steroidogenic tissues, the NADH can also be used to produce NADPH. For example, in mitochondria of luteal tissue, reducing equivalents are transferred from NADH to NADP+ by an energy-independent pyridine-nucleotide transhydrogenase [56]. Sonicates of luteal mitochondria are reported to catalyze the production of $60 \mathrm{nmol} \mathrm{NADPH} / \mathrm{min} / \mathrm{mg}$ protein from NADH [56]. Mitochondria in adrenal cortex tissue have a similar process, except that the transfer is energy-dependent [63]. The main source of NADPH in the mitochondria of luteal tissue is provided by $\mathrm{NADP}^{+}$-linked isocitrate dehydrogenase [56]. This enzyme is capable of reducing $253 \mathrm{nmol} \mathrm{NADP}+/ \mathrm{min} / \mathrm{mg}$ protein [56].

In the synthesis of progesterone, $\mathrm{NAD}^{+}$is reduced to $\mathrm{NADH}$. In order to maintain a high rate of progesterone synthesis, NADH has to be continually oxidized to $\mathrm{NAD}^{+}$. With microsomal HSD, the oxidation of NADH would have to occur via either the $\alpha$-glycerol phosphate shuttle or the malate-aspartate shuttle. Both shuttles transfer reducing equivalents from NADH into the mitochondria. However, the $\alpha$-glycerol phosphate shuttle does not operate in the ovary [64], which leaves the transfer of reducing equivalents to the malate-aspartate shuttle. The ovary already heavily utilizes this shuttle. As discussed earlier, the malate-aspartate shuttle transfers reducing equivalents from NADH into the mitochondria for the $\mathrm{P} 450_{\mathrm{scc}}$ enzyme. In addition, the shuttle is involved in the oxidation of the NADH produced during glycolysis. A high rate of glycolysis during the de novo synthesis of cholesterol, for example, generates high levels of NADH. If the levels of NADH exceed the carrying capacity of the shuttle system, the reducing equivalents are transferred to pyruvate via the enzyme, lactate dehydrogenase. A high level of lactate is a signal that the shuttle system is rate limiting.

The ovary produces appreciable amounts of lactate, even during the early follicular phase [65]. As follicular size increases, lactate levels also increase [66], coinciding with the start of antrum formation and detectable estradiol$17 \beta$ secretion $[66,67]$. After the LH surge, the levels of lactate increase an additional 2.5 fold $[66,68]$. In luteal tissue, a high percentage of the glucose taken up is metabolized only as far as pyruvate and lactate [69]. Iodoacetate, an inhibitor of glycolysis, abolishes the effect of LH on lactate accumulation and significantly reduces LH-stimulated progesterone synthesis $[68,70]$.
The fact that the malate-aspartate shuttle is rate-limiting could be the reason for a mitochondrial location for HSD. However, pregnenolone is an end-product inhibitor of the $P 450_{\text {scc }}$ reaction $[71,72]$, and a mitochondrial location for HSD would remove the steroid from its site of inhibition. Progesterone does not inhibit the $\mathrm{P} 450_{\text {scc }}$ reaction [71]. Evidence that mitochondrial HSD is involved in the production of high levels of progesterone is provided by the observation that mitochondria from thecal tissue convert only $6.4 \%$ of total ${ }^{14} \mathrm{C}$-cholesterol to ${ }^{14} \mathrm{C}$-progesterone $(1.2 \%)$ and ${ }^{14} \mathrm{C}$-pregnenolone $(5.2 \%)$; whereas, in contrast, mitochondria from luteal tissue convert $16.1 \%$ of total ${ }^{14} \mathrm{C}$-cholesterol to ${ }^{14} \mathrm{C}$-progesterone $(13.5 \%)$ and ${ }^{14} \mathrm{C}$-pregnenolone (2.6\%) [73].

In human adrenals and gonads, HSD is derived from the same gene and has been classified as type II, relative to the placental enzyme, which is classified as type I $[27,28,74,75]$. In the adrenals and gonads of the rat [74$76]$ and mouse $[77,78]$, the enzyme is also derived from the same gene, which in these rodents is classified as type I. The fact that ovaries and adrenal cortex contain the same HSD enzyme indicates that their response to trophic hormone stimulation would also be the same. One would expect, therefore, that ACTH stimulation would cause an increase in mitochondrial HSD activity in adrenal cortex tissue. ACTH stimulation of male and female rats does cause an increase in HSD mRNA and HSD activity [79]. However, it is not known if ACTH stimulation causes a preferential increase in mitochondrial HSD activity.

Aside from the role that Steroidogenic Acute Regulatory protein (StAR) plays in controlling cholesterol access to mitochondria, the rate-limiting step in steroidogenesis is considered to be $\mathrm{P} 450_{\text {scc }}[80]$. However, the fact that $\mathrm{P}^{4} 50_{\text {scc }}$ and HSD are bound together as a complex [24] suggests that the rate-limiting step, or steps, entails the conversion of cholesterol to progesterone. There is a decided advantage in these two enzymes functioning as a unit. Instead of shuttling steroid intermediates from organelle to organelle, cholesterol can be converted to progesterone in what could be described as a single step. The levels of progesterone can be increased even further if the reactions of both enzymes are coupled together, which appears to be the case. The discovery of the energy-independent NADH/NADP+ transhydrogenase initially led to the assumption that it existed to supply $\mathrm{P} 450_{\mathrm{scc}}$ with NADPH [56]. However, the transhydrogenase is capable of producing less than one/half the NADPH needed to synthesize high levels of pregnenolone. If its function is to act as a principal supplier of NADPH, it is inadequate. However, if its main function is to ensure that HSD has an undiminished supply of $\mathrm{NAD}^{+}$, and is operating at $\mathrm{V}_{\max }$ it is more than adequate. It is an ideal means of coupling HSD to $P 450_{\text {scc. }}$. Unfortunately, the exchange of one 


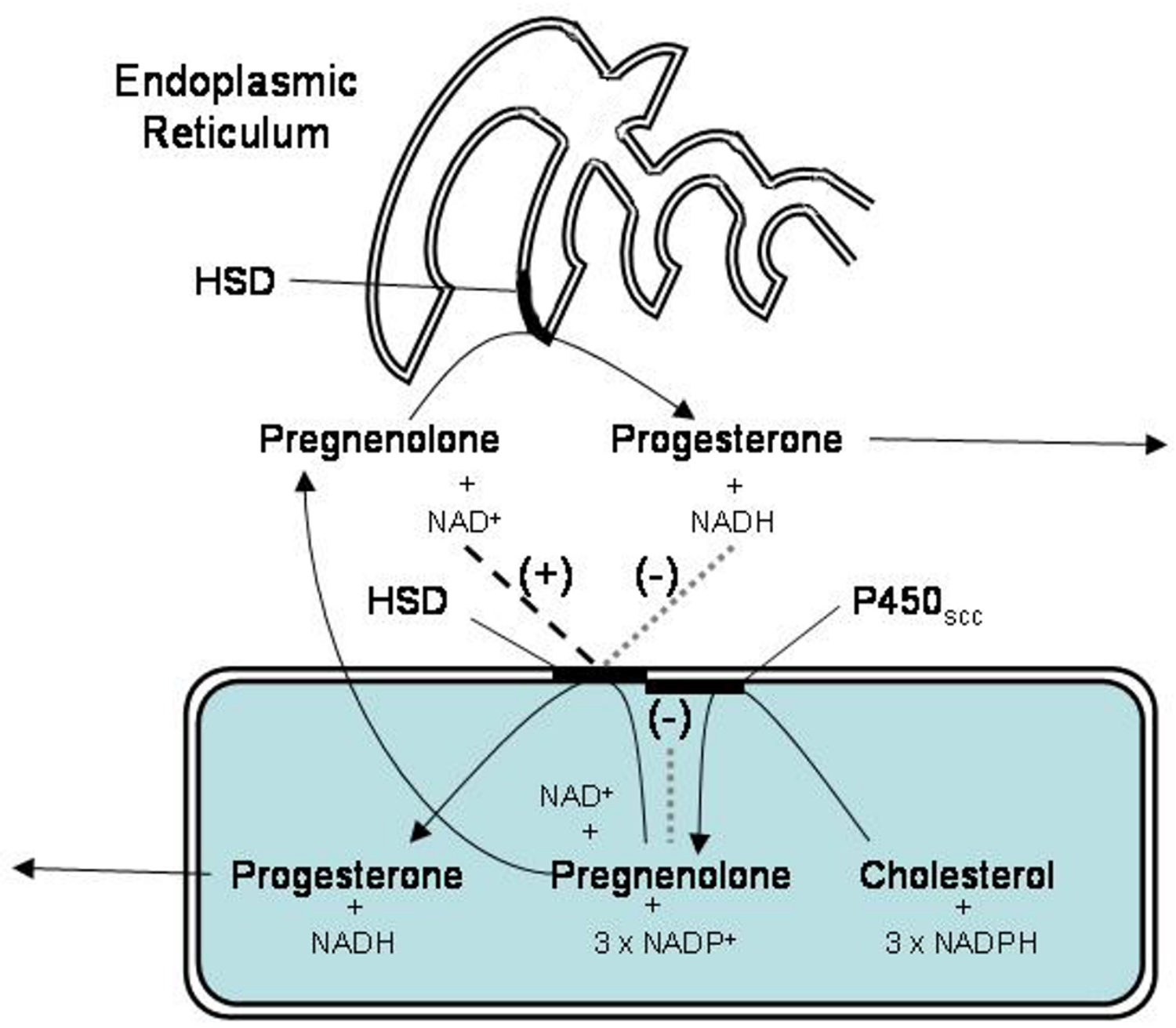

Mitochondrion

\section{Figure 5}

The proposed regulation of progesterone synthesis by pregnenolone and by extramitochondrial NAD+/NADH. In the overall conversion of cholesterol to progesterone, pregnenolone acts as an end product inhibitor in the $\mathrm{P}^{2} 5 \mathrm{scc}_{\text {scc }}$ reaction, [-..... (-)]; and, in the mitochondrial HSD reaction, extramitochondrial NAD ${ }^{+}$operates as an allosteric activator [-----(+)] and extramitochondrial NADH operates as an allosteric inhibitor $[\cdots \cdots \cdot(-)]$.

molecule of NADH to produce one molecule of NADPH is insufficient for the overall conversion of progesterone to cholesterol. This is because the $\mathrm{P} 450_{\text {scc }}$ reaction utilizes 3 molecules of NADPH for the synthesis of one molecule of pregnenolone. The remainder of the NADPH for this reaction would have to be supplied by mitochondrial NADP+-linked isocitrate dehydrogenase [56].
The $\mathrm{P}^{4} 50_{\text {scd }} / \mathrm{HSD}$ enzyme complex is well regulated. In addition to the end-product inhibition exerted by pregnenolone on the $P 450_{\text {scc }}$ reaction $[71,72]$, the HSD reaction is affected by the redox state of cytoplasmic pyridine nucleotides [81]. For example, extramitochondrial NAD ${ }^{+}$ increases mitochondrial HSD activity by up to $40 \%$; whereas, extramitochondrial NADH inhibits HSD activity 
by as much as $70 \%$. Figure 5 is a representative diagram of the proposed regulation of the conversion of cholesterol to progesterone. As indicated, pregnenolone acts as an end product inhibitor of the $\mathrm{P}^{4} 50_{\mathrm{scc}}$ reaction, $[\cdots \cdots$ $(-)]$; and, in the mitochondrial HSD reaction, extramitochondrial $\mathrm{NAD}^{+}$operates as an allosteric activator [----$(+)]$ and extramitochondrial NADH operates as an allosteric inhibitor $[\cdots \cdots(-)]$. With this level of control it is difficult to imagine how pregnenolone could ever leave the luteal cells without being converted to progesterone.

Finally; it was noted in the results section that total ovarian protein was inversely correlated with the peaks of LH. A decrease in total ovarian protein during diestrus could be due to ovulation. However, this does not explain the lower protein levels following LH stimulation that occurs during pregnancy and after parturition. A rapid and ongoing synthesis of the two enzymes, $\mathrm{P} 450_{\text {scc }}$ and HSD is critical to the production of high levels of progesterone. This necessitates a ready supply of amino acids. It is speculative of course, but the action of LH could include the initiation of proteolysis of protein stores from luteal tissue, which could explain the lower protein levels.

\section{Conclusion}

The ovary has two levels of steroid synthesis. One level occurs during the follicular phase, and a higher level of synthesis occurs throughout the luteal phase. We believe the higher level of synthesis is due to, and the reason for, mitochondrial HSD. To synthesize estradiol-17 $\beta$ during the follicular phase, steroid precursors are shuttled from cell type to cell type and from organelle to organelle. The synthesis of progesterone during the luteal phase involves one cell type and two enzymes. With HSD in the mitochondria, rather than in the microsomes, the shuttle of steroid precursors is unnecessary. It also allows for HSD and $\mathrm{P} 450_{\text {scc }}$ to function together as a unit, a decided advantage for producing high levels of progesterone. This is especially true if the two enzymes are coupled together by the NADH/NADP+ transhydrogenase. A mitochondrial location for HSD also solves the problem inherent with the rate-limiting malate-aspartate shuttle, and it removes the end-product inhibition of pregeneolone by converting it to progesterone. Finally, the fact that HSD and P450 scc have a strong binding affinity for each other, and are synthesized simultaneously, tentatively suggests a means by which LH stimulation results in an increase in mitochondrial HSD activity.

\section{References}

I. Beyer KL, Samuels LT: Distribution of the steroid-3/-ol dehydrogenase in cellular structures of the adrenal gland. J Biol Chem 1956, 219:69-76.

2. Armstrong DT, Jackanicz, Keyes PL: Regulation of steroidogenesis in the rabbit ovary. In The gonads Edited by: Mckerns KW. Amsterdam, North-Holland Publishing Co; 1969:3-25.
3. Sulimovici S, Boyd GS: The $\Delta^{5}-3 \beta$-hydroxysteroid dehydrogenase of rat ovarian tissue: the effect of adenosine 3',5' cyclicmonophosphate acid. Eur J Biochem 1969, 7:549-558.

4. Dimino MJ, Campbell MD: Progesterone synthesis by luteal mitochondria in vitro. Proc Soc Exp Biol Med 1976, 152:54-56.

5. Sulimovici S, Bartoov , Lunenfeld B: Localization of 3- $\beta$-hydroxysteroid dehydrogenase in the inner membrane subfraction of rat testis mitochondria. Biochem Biophys Acta 1973, 321:27-40.

6. van der Vusse GJ, Kalkman ML, van der Molen HJ: 3 3 -Hydroxysteroid dehydrogenase in rat testis tissue. Inter- and subcellular localization and inhibition by cyanoketone and nagarse. Biochem Biophys Acta 1974, 348:404-4I4.

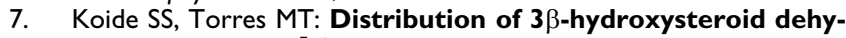
drogenase and $\Delta^{5}$-3-oxosteroid isomerase in homogenate fractions of human term placenta. Biochem Biophys Acta 1965, 105: II5-120.

8. Ferre F, Breuiller M, Cedard L, Duchesne M-J, Saintato M, Descomps $B$, Crastes de Paulet A: Human placental $\Delta^{5}-3 \beta$ hydroxysteroid dehydrogenase activity: intracellular distribution, kinetic properties, retroinhibition and influence of membrane delipidation. Steroids 1975, 26:55I-570.

9. Edwards DP, O'Conner JL, Bransome ED Jr, Braselton WE Jr: Human placental $3 \beta$-hydroxysteroid dehydrogenase $/ \Delta^{5}$-isomerase. Demonstration of an intermediate in the conversion of 3 $\beta$-hydroxypregn-5-en-20-one to pregn-4-ene-3, 20dione. J Biol Chem 1976, 25 I:1632-I638.

10. Meigs RA, Sheean LA: Mitochondria from human term placenta. III. The role of respiration and energy generation in progesterone synthesis. Biochim Biophys Acta 1977, 489:225-235.

II. McCune RW, Roberts S, Young PL: Competitive inhibition of adrenal $\Delta^{5}-3 \beta$-hydroxysteroid dehydrogenase and $\Delta^{5}$-3-ketosteroid isomerase activities by adenosine 3', 5'-monophosphate. J Biol Chem 1970, 245:3859-3867.

12. Basch RS, Finegold MJ: $3 \beta$-Hydroxysteroid dehydrogenase activity in the mitochondria of rat adrenal homogenates. Biochem J 1971, 125:983-989.

13. Hochberg RB, Ladany S, Welch M, Lieberman S: Cholesterol and cholesterol sulfate as substrates for the adrenal side-chain cleavage enzyme. Biochemistry 1974, 13:1938-1945.

14. Kream BE, Sauer LA: On the intracellular localization of the 33hydroxysteroid dehydrogenase/isomerase in the rat adrenal cortex. Proc Soc Exp Biol Med 1976, I 52:459-462.

15. Moustafa AM, Koritz SB: Concerning the subcellular distribution of $3 \beta$-hydroxysteroid dehydrogenase/isomerase in the rat adrenal. Proc Soc Exp Biol Med 1975, 149:823-825.

16. Caffrey JL, Nett TM, Abel JH Jr, Niswender GD: Activity of 3 $\beta$ hydroxy- $\Delta^{5}$ - steroid dehydrogenase $/ \Delta^{5}-\Delta^{4}$-isomerase in the ovine corpus luteum. Biol Reprod 1979, 20:279-287.

17. Cowan RA, Giles CA, Grant JK: The intramitochondrial distribution of 3 3 -hydroxysteroid dehydrogenase-oxosteroid isomerase. A probable redistribution artifact. J Steroid Biochem 1974, 5:607-608.

18. Chapman JC, Sauer LA: Intracellular localization and properties of $3 \beta$-hydroxysteroid dehydrogenase/isomerase in the adrenal cortex. J Biol Chem 1979, 254:6624-6630.

19. Sholl SA: $3 \beta-H y d r o x y s t e r i o d$ dehydrogenase $/ \Delta^{5}-\Delta^{4}$ isomerase activity in the rhesus monkey placenta and fetal adrenal, testis and ovary during late gestation. Steroids 1983, 41:757-768.

20. Cherradi N, Defaye G, Chambaz EM: Dual subcellular localization of the $3 \beta$-hydroxysteroid dehydrogenase isomerase: characterization of the mitochondrial enzyme in bovine adrenal cortex. J Steroid Biochem Mol Biol 1993, 46:773-779.

21. Cherradi N, Defaye G, Chambaz EM: Characterization of the $3 \beta-$ hydroxysteroid dehydrogenase activity associated with bovine adrenocortical mitochondria. Endocrinology 1994, 134:1358-1364.

22. Hiura M, Nogawa T, Fujiwara A: Electron microscopy of cytodifferentiation and its subcellular steroidogenic sites in the thecal cell of the human ovary. Histochemistry 198I, 71:269-277.

23. Pelletier G, Li S, Luu-The V, Tremblay Y, Belanger A, Labrie F: Immunoelectron microscopic localization of three key steroidogenic enzymes (cytochrome P450(scc), 3 $\beta$-hydroxysteroid dehydrogenase and cytochrome $\mathrm{P450}$ (cl7)) in rat adrenal cortex and gonads. J Endocrinol 200I, I 71:373-383.

24. Cherradi N, Chambaz EM, Defaye G: Organization of $3 \beta$ hydroxysteroid dehydrogenase/isomerase and cytochrome 
P450 into a catalytically active molecular complex in bovine adrenocortical mitochondria. J Steroid Biochem Mol Biol 1995, 55:507-5 |4.

25. Thomas JL, Meyers RP, Strickler RC: Human placental 3 $\beta$ hydroxy-5-ene-steroid dehydrogenase and steroid $5 \rightarrow 4$ ene-isomerase: purification from mitochondria and kinetic profiles, biophysical characterization of the purified mitochondrial and microsomal enzymes. J Steroid Biochem 1989, 33:209-217.

26. Luu-The $V$, Takahashi M, Labrie F: Purification of microsomal and mitochondrial $3 \beta$-hydroxysteroid dehydrogenase $/ \Delta^{5}-\Delta^{4}$ isomerase from human placenta. Ann NY Acad Sci 1990 , 595:386-388.

27. Thomas JL, Evans BW, Blanco G, Mason JI, Strickler RC: Creation of a fully active, cytosolic form of human type I 3 $\beta$-hydroxysteroid dehydrogenase/isomerase by the deletion of a membrane spanning domain. J Mol Endocrinol 1999, 23:23I-239.

28. Thomas JL, Mason Jl, Blanco G, Veisaga ML: The engineered, cytosolic form of human type I $\beta$-hydroxysteroid dehydrogenase/isomerase: purification, characterization and crystallization. I Mol Endocrinol 200I, 27:77-83.

29. Chapman JC, Waterhouse TB, Michael SD: Changes in mitochondrial and microsomal 3 $\beta$-hydroxysteroid dehydrogenase activity in mouse ovary over the course of the estrous cycle. Biol Reprod 1992, 47:992-997.

30. Richards JS, Jahnsen T, Hedin L, Lifka J, Ratoosh S, Durica JM, Goldring NB: Ovarian follicular development: from physiology to molecular biology. Rec Prog Horm Res 1987, 43:23I-276.

31. Richards JS, Hedin I: Molecular aspects of hormone action in ovarian follicular development, ovulation, and luteinization. Ann Rev Physiol 1988, 50:44I-463.

32. Murr SM, Bradford GE, Geschwind II: Plasma luteinizing hormone, follicle-stimulating hormone and prolactin during pregnancy in the mouse. Endocrinology 1974, 94:1 I2-116.

33. Murr SM, Stabenfeldt GH, Bradford GE, Geschwind II: Plasma progesterone during pregnancy in the mouse. Endocrinology 1974 , 94:|209-|2||.

34. Rugh R: Reproductive systems of adult mice. In The Mouse, its Reproduction and Development Oxford, Oxford University Press; 1990:24-43.

35. Wharton DC, Tzagoloff A: Cytochrome c oxidase from beef heart mitochondria. Methods Enzymol 1967, 10:245-250.

36. Bradford MM: A rapid and sensitive method for the quantitation of microgram quantities of protein utilizing the principle of protein-dye binding. Anal Biochem 1976, 72:248-254

37. Goldring NB, Durcia JM, Lifka J, Hedin L, Ratoosh SL, Miller WL, Orly J, Richards JS: Cholesterol side-chain cleavage $\mathbf{P 4 5 0}$ messenger ribonucleic acid: evidence for hormonal regulation in rat ovarian follicles and constitutive expression in corpora lutea. Endocrinology 1987, 1 20:1942-1950.

38. Mason JI, Keeney DS, Bird IM, Rainey WE, Morohashi K-I, LeersSucheta S, Melner MH: The regulation of 3 $\beta$-hydroxysteroid dehydrogenase expression. Steroids 1997, 62:164-168.

39. Juneau C, Dupont E, Luu-The V, Labrie F, Pelletier G: Ontogenesis of 3 $\beta$-hydroxysteroid dehydrogenase $\Delta^{5}-\Delta^{4}$ isomerase in the rat ovary as studied by immunocytochemistry and in situ hybridization. Biol Reprod 1993, 48:226-234.

40. Zhao H-F, Labrie C, Simard J, de Launoit Y, Trudel C, Martel C, Rheaume E, Dupont E, Luu-The V, Pelletier G, Labrie F: Characterization of rat $3 \beta$-hydroxysteroid dehydrogenase $/ \Delta^{5}-\Delta^{4}$ isomerase cDNAs and differential tissue-specific expression of the corresponding mRNAs in steroidogenic and peripheral tissues. J Biol Chem 1991, 266:583-593.

4I. Couet J, Martel C, Dupont E, Luu-The V, Sirard M-A, Zhao H-F, Pelletier G, Labrie F: Changes in 3 $\beta$-hydroxysteroid dehydrogenase $/ \Delta^{5}-\Delta^{4}$-isomerase messenger ribonucleic acid, activity and protein levels during the estrous cycle in the bovine ovary. Endocrinology 1990, 1 27:2141-2148.

42. Conley AJ, Kaminski MA, Dubowsky SA, Jablonka-Shariff A, Redmer DA, Reynolds LP: Immunohistochemical localization of $3 \beta$ hydroxysteroid dehydrogenase and P450 $17 \alpha$-hydroxylase during follicular development in pigs, sheep, and cows. Biol Reprod 1995, 52:1081-1094.

43. Hawkins DE, Belfiore CJ, Kile JP, Niswender GD: Regulation of messenger ribonucleic acid encoding $3 \beta$-hydroxysteroid dehydrogenase $/ \Delta^{5}-\Delta^{4}$ isomerase in the ovine corpus luteum. Biol Reprod 1993, 48: I I85-II 90.

44. Juengel JL, Guy MK, Tandeski TR, McGuire WJ, Niswender GD: Steady-state concentrations of messenger ribonucleic acid encoding cytochrome P450 side-chain cleavage and $3 \beta$ hydroxysteroid dehydrogenase/ $\Delta 5-\Delta 4$-isomerase in ovine corpora lutea during the estrous cycle. Biol Reprod 1994, $51: 380-384$

45. Boerboom D, Sirois J: Equine $\mathbf{P 4 5 0}$ cholesterol side-chain cleavage and $3 \beta$-hydroxysteroid dehydrogenase $/ \Delta^{5}-\Delta^{4}$ isomerase: molecular cloning and regulation of their messenger ribonucleic acids in equine follicles during the ovulatory process. Biol Reprod 200I, 64:206-2I5

46. Bassett SG, Little-lhrig LL, Mason JI, Zeleznik AJ: Expression of messenger ribonucleic acids that encode for $3 \beta$-hydroxysteroid dehydrogenase and cholesterol side-chain cleavage enzyme throughout the luteal phase of the macaque menstrual cycle. I Clin Endocrinol Metab 1991, 72:362-366.

47. Doody KJ, Lorence MC, Mason JI, Simpson ER: Expression of messenger ribonucleic acid species encoding steroidogenic enzymes in human follicles and corpora lutea throughout the menstrual cycle. J Clin Endocrinol Metab 1990, 70:104I-1045.

48. Dupont E, Labrie F, Luu-The V, Pelletier G: Immunocytochemical localization of $3 \beta$-hydroxysteroid dehydrogenase $/ \Delta^{5}-\Delta^{4}$ isomerase in human ovary. J Clin Endocrinol Metab 1992, 74:994-998.

49. Suzuki T, Sasano H, Tamura M, Aoki H, Fukaya T, Yajima A, Nagura $H$, Mason Jl: Temporal and spatial localization of steroidogenic enzymes in premenopausal human ovaries: in situ hybridization and immunohistochemical study. Mol Cell Endocrinol 1993, 97:135-143.

50. Herbst AL: Response of rat ovarian cholesterol to gonadotropins and anterior pituitary hormones. Endocrinology 1967, $81: 54-60$.

51. Bjersing L: On the ultrastructure of granulosa lutein cells in porcine corpus luteum. With special reference to endoplasmic reticulum and steroid hormone synthesis. Z Zellforsch Mikrosk Anat 1967, 82:|87-2II.

52. Savard K, Marsh JM, Rice BF: Gonadotropins and ovarian steroidogenesis. Rec Prog Hormon Res 1965, 21:285-365.

53. Armstrong DT: Gonadotropins, ovarian metabolism, and steroid biosynthesis. Rec Prog Horm Res 1968, 24:255-319.

54. Flint APF, Denton RM: Glucose metabolism in the superovulated rat ovary in vitro. Biochem J 1969, I | 2:243-254.

55. Flint APF, Denton RM: The role of nicotinamide-adenine dinucleotide phosphate-dependent malate dehydrogenase and isocitrate dehydrogenase in the supply of reduced nicotinamide-adenine dinucleotide phosphate for steroidogenesis in the superovulated rat ovary. Biochem J 1970, I I 7:73-83.

56. Robinson J, Stevenson PM: Electron flow and cholesterol-sidechain cleavage in ovarian mitochondria. Eur J Biochem 1971, 24:18-30.

57. Simpson ER, Estabrook RW: A possible mechanism for the transfer of cytosol-generated NADPH to the mitochondrial mixed-function oxidases in bovine adrenal cortex: a malate shuttle. Arch Biochem Biophys 1968, I 26:977-978.

58. Simpson ER, Estabrook RW: The "malate shuttle" and control of steroid hydroxylation in the adrenal cortex. Adv Enzyme Regul 1969, 7:259-279.

59. Stevenson PM, Forman E: Malate and gonadotropin stimulation of rat ovary. J Endocrinol 1971, 49:22-23.

60. Stevenson PM, Taylor PL: "Malic enzyme" and alkaline phosphatase in mitochondria from pig and rat ovaries. FEBS Lett 1971, 19:251-254.

61. Simpson ER, Estabrook RW: Mitochondria malic enzyme: the source of reduced nicotinamide adenine dinucleotide phosphate for steroid hydroxylation in bovine adrenal cortex mitochondria. Arch Biochem Biophys 1969, 129:384-395.

62. Sauer LA: An NAD ${ }^{+}$- and $\mathrm{NADP}^{+}$-dependent malic enzyme with regulatory properties in rat liver and adrenal cortex mitochondrial fractions. Biochem Biophys Res Commun 1973, 50:524-531.

63. Cammer W, Estabrook RW: Respiratory activity of adrenal cortex mitochondria during steroid hydroxylation. Arch Biochem Biophys 1967, I 22:72I-734.

64. Knodel EL, Doeg KA: Transfer of reducing equivalents in the rat polycystic ovary. J Endocrinol 1977, 72:107-108. 
65. Zeilmaker GH, Verhamme CM: Lactate concentrations in preovulatory follicles of pro-oestrus rats before and after onset of oocyte maturation. Acta Endocrinol 1977, 86:380-383.

66. Harlow CR, Winston RML, Margara RA, Hillier SG: Gonadotrophic control of human granulosa cell glycolysis. Human Reprod 1987, 2:649-653.

67. Boland NI, Humpherson PG, Leese HJ, Gosden RG: Pattern of lactate production and steroidogenesis during growth and maturation of mouse ovarian follicles in vitro. Biol Reprod 1993, 48:798-806

68. Lieberman ME, Ahren K, Tsafriri A, Bauminger S, Linder HR: Relationship between glycolysis and steroidogenesis in cultured Graafian follicles stimulated by LH or prostaglandin E2. J Steroid Biochem 1975, 6:1445-1449.

69. Armstrong DT: Stimulation of glycolytic activity of rat corpus luteum tissue by luteinizing hormone. Endocrinology 1963, 72:908-913.

70. Linder HR, Tsafriri A, Lieberman E, Zor U, Koch Y, Bauminger S, Barnea A: Gonadotropin action on cultured Graafian follicles: induction of maturation division of the mammalian oocyte and differentiation of the luteal cell. Rec Prog Horm Res 1974, 30:79-138.

7I. Koritz SB, Hall PF: End-product inhibition of the conversion of cholesterol to pregnenolone in an adrenal extract. Biochemistry 1964, 3:1298-1304.

72. Koritz SB, Hall PF: Feedback inhibition by pregnenolone: A possible mechanism. Biochim Biophys Acta 1964, 93:2 I5-217.

73. Dimino MJ: Differences in mitochondrial steroidogenesis between follicular and luteal tissues of porcine ovaries. Endocrinology 1977, I0 I: 1844- I849.

74. Pelletier G, Dupont E, Simard J, Luu-The V, Belanger A, Labrie F: Ontogeny and subcellular localization of $3 \beta$-hydroxysteroid dehydrogenase (3 $\beta$-HSD) in the human and rat adrenal, ovary and testis. J Steroid Biochem Mol Biol 1992, 43:45 I-467.

75. Zhao H-F, Labrie C, Simard J, de Launoit Y, Trudel C, Martel C, Rheaume E, Dupont E, Luu-The V, Pelletier G, Labrie F: Characterization of rat $3 \beta$-hydroxysteroid dehydrogenase $/ \Delta^{5}-\Delta^{4}$ isomerase cDNAs and differential tissue-specific expression of the corresponding mRNAs in steroidogenic and peripheral tissues. J Biol Chem I99I, 266:583-593.

76. Simard J, de Launoit Y, Labrie F: Characterization of the structure-activity relationships of rat types I and II 3 $\beta$-hydroxysteroid dehydrogenase $/ \Delta^{5}-\Delta^{4}$ isomerase by site-directed mutagenesis and expression in HeLa cells. J Biol Chem I991, 266: | 4842- | 4845

77. Bain PA, Yoo M, Clarke T, Hammond SH, Payne AH: Multiple forms of mouse $3 \beta$-hydroxysteroid dehydrogenase $/ \Delta^{5}-\Delta^{4}$ isomerase and differential expression in gonads, adrenal glands, liver, and kidneys of both sexes. Proc Natl Acad Sci I 991, 88:8870-8874.

78. Abbaszade IG, Arensburg J, Park C-H, Kasa-Vubu JZ, Orly J, Payne $\mathrm{AH}$ : Isolation of a new mouse $3 \beta$-hydroxysteroid dehydrogenase isoform, $3 \beta$-HSD VI, expressed during early pregnancy. Endocrinology 1997, I38:1392-1399.

79. Trudel C, Couet J, Martel C, Labrie C, Labrie F: Regulation of adrenal 3 $\beta$-hydroxysteroid dehydrogenase $/ \Delta^{5}-\Delta^{4}$-isomerase expression and activity by adrenocorticotropin and cortisone in the rat. Endocrinology 1991, I29:2077-2084.

80. Miller WL: Mitochondrial specificity of the early steps in steroidogenesis. J Steroid Biochem Mol Biol 1995, 55:607-6I6.

8I. Sauer LA, Chapman JC, Dauchy RT: Topology of $\beta$-hydroxy-5ene-steroid dehydrogenase $/ \Delta^{5}-\Delta^{4}$-isomerase in adrenal cortex mitochondria and microsomes. Endocrinology 1994, I34:75I-759.
Publish with Biomed Central and every scientist can read your work free of charge

"BioMed Central will be the most significant development for disseminating the results of biomedical research in our lifetime. "

Sir Paul Nurse, Cancer Research UK

Your research papers will be:

- available free of charge to the entire biomedical community

- peer reviewed and published immediately upon acceptance

- cited in PubMed and archived on PubMed Central

- yours - you keep the copyright

Submit your manuscript here:

http://www.biomedcentral.com/info/publishing_adv.asp
BioMedcentral 